\title{
The nerve protection and in vivo therapeutic effect of Acalypha indica extract in frogs
}

\author{
Ernie H. Purwaningsih, ${ }^{1}$ Nurhadi Ibrahim, ${ }^{2}$ Hamdani Zain ${ }^{3}$ \\ ${ }^{1}$ Department of Pharmacy, Faculty of Medicine, University of Indonesia, Jakarta, Indonesia \\ ${ }^{2}$ Department of Physiology, Faculty of Medicine, University of Indonesia, Jakarta, Indonesia \\ ${ }^{3}$ Department of Medical Physics, Faculty of Medicine, University of Indonesia, Jakarta, Indonesia
}

\begin{abstract}
Abstrak
Tujuan Membuktikan efek neuroproteksi dan/atau neuroterapi ekstrak air Acalypha indica Linn. pada katak yang dilumpuhkan dengan injeksi pankuronium bromida

Metode Enam puluh ekor katak (Bufo melanostictus Schneider) dibagi ke dalam dua kelompok perlakuan yaitu kelompok neuroproteksi dan neuroterapi. Setiap kelompok dibagi ke dalam 6 subkelompok yaitu kontrol negatif (diberi air); kontrol positif (pirasetam), dan 4 kelompok dosis ekstrak: 200, 300, 400, 500 mg/KgBB. Pankuronim bromida 0,2\%, pelumpuh otot, disuntikkan subkutan pada punggung katak. Untuk efek proteksi, ekstrak diberikan per oral 1 jam sebelum disuntik, sedangkan untuk efek terapi ekstrak diberikan, sepuluh menit sesudah penyuntikan pankuronium bromida. Parameter yang diukur adalah waktu (menit) timbul dan lama kelumpuhan, serta waktu untuk perbaikan.
\end{abstract}

Hasil penelitian menunjukkan bahwa pada dosis ekstrak 400 dan 500 mg/KgBB terjadi efek neuroproteksi yang berbeda bermakna dibanding kontrol negatif dan pirasetam $(p<0.05)$. Ekstrak pada dosis 200-500 mg/KgBB menunjukkan efek neuroterapi yang berbeda bermakna dibandingkan kontrol negatif $(p=0,000)$ dan tidak berbeda bermakna dibandingkan pirasetam, kecuali pada dosis ekstrak $300 \mathrm{mg} / \mathrm{KgBB}$, menunjukkan efek lebih baik dibandingkan dengan pirasetam $(p=0,012)$.

Kesimpulan Bahwa ekstrak air Acalypha indica Linn. memiliki efek neuroproteksi dan neuroterapi yang sama atau lebih baik dibandingkan pirasetam pada katak yang dilumpuhkan dengan pankuronium bromida. Namun, masih diperlukan uji farmakodinamik dan farmakokinetik pada dua model hewan coba yang lazim digunakan. (Med $\mathbf{J}$ Indones 2010; 19:96-102)

\begin{abstract}
Aim To demonstrate nerve protection and/or treatment effect of Acalypha indica Linn. extract on nerve paralysis induced by subcutaneus injection of pancuronium bromide on frog's back.

Methods The study was performed on sixty frogs (Bufo melanostictus Schneider) that divided into two groups, i.e. the neuro-protection and neuro-therapy group. Each group was divided further into 6 sub-treatment groups: negative control group treated by water and positive control group treated by piracetam, treatment groups received the extracts $200,300,400,500 \mathrm{mg} / \mathrm{kgBW}$. Pancuronium bromide $0.2 \%$ (1:20 dilutions) were injected subcutaneously as muscle relaxant. The protective effect was studied by giving the extract orally, 1 hour prior to injection; while the therapeutic effect of the extract was studied by 10 minute treatment after injecting pancuronium bromide solution. The parameters measured were the onset and duration of paralysis (in minutes) and the recovery time (time needed to recover into normal condition).

Results The study showed significantly different protective effect of Acalypha indica Linn. root water extract at 400 and $500 \mathrm{mg} / \mathrm{Kg}$.BW compared to negative control group and positive control group (piracetam $(\mathrm{p}<0.05)$; while the therapeutic effect was obvious at the dose $200-500 \mathrm{mg} / \mathrm{Kg}$.BW compared to negative control group ( $\mathrm{p}=0.000)$. There was no significant difference compared to positive control group (piracetam), except at $300 \mathrm{mg} / \mathrm{Kg} . \mathrm{BW}$ (p=0,012).

Conclusion These results have proven that the water extract of Acalypha indica Linn. root has comparable protective and treatment effect on nerves system, as piracetam, but further studies should be performed to provide more evidences particularly pharmacokinetic and pharmacodynamic studies on two animal models that commonly used. (Med $\boldsymbol{J}$ Indones 2010; 19:96-102)
\end{abstract}

Key words: Acalypha indica Linn, Bufo melanostictus Schneider, nerve-protection 
In 2006, the morbidity rate of stroke incidence in patients with hypertension due to cerebral thrombosis was about $83 \%$, while $70 \%$ of these cases were caused by cerebral hemorrhage. One third of these patients recovered successfully from remaining symptoms, but two thirds of them had still persistent neurological disorders characterized by musculoskeletal paralysis such as hemiplegia or hemiparese. ${ }^{1}$

To treat such persistent symptoms, various conventional chemical drugs have been used despite their high cost, uncertain or still questionable efficacy between their benefit and risk, and/or aggravating side effects such as sleeping disorder, anxiety and depression, e.g., piracetam. $^{2}$

Hypertensive patients often turned their choice to alternative or complementary traditional herbal medicine, such as celery (Apium graveolens Linn.) $)^{3}$, garlic (Allium sativum Linn.) ${ }^{4}$, and mahkota dewa (Phaleria marcocarpa Scheff. $)^{5}$. These herbs are consumed separately or in combination to treat hypertension but not as remedies for paralysis or hemi-/paraplegia that may have occurred as a result of the hypertensioncaused stroke and its remaining post-stroke symptoms.

In some Indonesian communities, root extract with boiling water of akar kucing (Acalypha indica Linn.) has been used traditionally to reduce or even heal such remaining symptoms. However, no data has been established as a reference on the beneficial magnitude of Acalypha indica in the treatment of neurological disorders in vivo.

Previously, it was demonstrated that the aqueous root extract from Acalypha indica Linn. has neuro-protective and neuro-therapeutic effects on gastrocnemius muscles of frogs in ex vivo studies ${ }^{6}$. Therefore, a similiar experimental in vivo study in frogs was performed. The frogs were considered as an experimental animal model based on the data of these previous studies which used isolated frog nerves and muscles ex vivo in order to examine membrane transport and activity of neurotransmitters. ${ }^{7-8}$

In a preliminary study ${ }^{6}$, pancuromium bromide was used as a model substance to induce neural paralysis and its dosage was adjusted to $2 \mathrm{mg} / \mathrm{ml}(0.2 \%)$ at 1:20 dilution for subcutaneous (s.c.) administration, equivalent to $0.1 \mathrm{mg}$ per frog.

The dosage of root extract was determined based on the ex vivo studies to $6,9,12,15 \mathrm{mg}$ or $200,300,400,500$ $\mathrm{mg} / \mathrm{kgBW}$, respectively, at an average body weight per frog of 30 grams.

From the ex vivo studies, it was expected that the results of the present study would also demonstrate protective and/or therapeutic effects of the root extract from Acalypha indica L. on the frogs' nerve system in vivo. Therefore, this animal model was chosen as a novel access in this preliminary study.

The general objective of this study was to prove that the root extract of Acalypha indica Linn. (akar kucing) has neural protective and therapeutic effects in vivo.

The specific objective was to prove that the root extract of Acalypha indica Linn. in a dose range of 6,9,12 and $15 \mathrm{mg}$ or $200,300,400,500 \mathrm{mg} / \mathrm{kgBW}$ has protecting and therapeutic effects on the nerves innervating the frog musculoskeletal system in vivo paralyzed by subcutaneous injection of pancuronium bromide.

\section{METHODS}

The animal model: This in vivo study was performed with 60 frogs in a weight range of $30 \pm 3.0$ grams at the Department of Medical Pharmacy and Department of Physiology, Faculty of Medicine, University of Indonesia, from December 2007 to April 2008. The frogs identified as Bufo melanostictus Schneider by Bogoriensis Laboratory of LIPI, Bogor, were provided by the Department of Physiology, Faculty of Medicine, University of Indonesia.

The extract dosage was adjusted to $200,300,400,500$ $\mathrm{mg} / \mathrm{kgBW}$ or $6,9,12,15 \mathrm{mg}$ for each frog, respectively, and piracetam as the positive control at $30 \mathrm{mg} /$ frog or $1,000 \mathrm{mg} / \mathrm{kgBW}$. Pancuronium bromide $0.1 \mathrm{mg}$ per frog was administered by subcutaneous (s.c.) injection. This dosage had been optimised experimentally in a preliminary study ${ }^{6}$.

\section{Group I: Neuroprotective effect}

This part of the study was conducted in six subgroups: negative control (water); positive control (piracetam); the aqueous root extract of Acalypha indica Linn. with doses of $6 \mathrm{mg} ; 9 \mathrm{mg} ; 12 \mathrm{mg} ; 15 \mathrm{mg}$ per frog, were given orally an hour before s.c. administration of pancuronium bromide $0.1 \mathrm{mg}$. The onset of action and duration of paralysis (in minutes) and the time (scored) needed to recover to normal condition were the parameters measured. 


\section{Group II: Neurotherapeutic effect}

This part of the study was also conducted in six subgroups: negative control (water); positive control (piracetam); the aqueous root extract of Acalypha indica Linn. with doses of $6 \mathrm{mg} ; 9 \mathrm{mg} ; 12 \mathrm{mg} ; 15 \mathrm{mg}$ per frog, were given orally, 10 minutes after subcutaneous injection of pancuronium bromide. The duration of paralysis (in minutes) and scored recovery time to normal condition were the parameters measured.

\section{Statistics}

Each group in this study consisted of 5 frogs, thus SD was evaluated from $n=5$. The onset of action (only for protection), duration of paralysis and recovery time (in minutes), both for protective or therapeutic effects were analyzed statistically by using one-way Anova with limit of significance at $\mathrm{p}=0.05 .{ }^{9}$

\section{RESULTS}

\section{Group I: Neuroprotective effects (Figs.1-3).}

Neuroprotective effects in frogs paralyzed with $0.1 \mathrm{mg}$ pancuronium bromide in vivo showed a maximum at dose $12 \mathrm{mg}$ or $400 \mathrm{mg} / \mathrm{kgBW}$, but the entire dose range from $6 \mathrm{mg}$ to $15 \mathrm{mg}$ (or $200-500 \mathrm{mg} / \mathrm{kgBW}$ ) had equivalent or even stronger effects than the positive control group with piracetam 30mg.

\section{Onset of paralysis}

Figure 1 shows that frogs which obtained the extract one hour before injection of pancuronium bromide, experienced paralysis within 14-25 minutes, whereas in the negative control group onset of paralysis was after $9 \pm 1.4$ minutes and in the positive control group of piracetam after $11 \pm 1.6$ minutes. In other words, onset of paralysis was slower over the whole range dose from $6 \mathrm{mg}$ to $15 \mathrm{mg}$ of extract as compared to both, negative and positive controls. The peak of efficacy in this experiment is at $25 \pm 2.2$ minutes with $12 \mathrm{mg}$ of extract (Fig.1). The protective effect of $12 \mathrm{mg}$ and $15 \mathrm{mg}$ $(22 \pm 2.0 \mathrm{~min}$.) of extract is significantly different from both negative and positive controls $(\mathrm{p}<0.05)$.

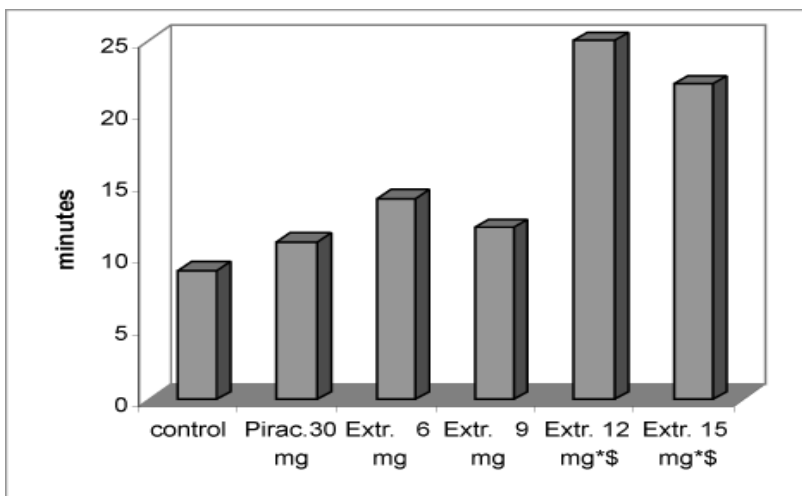

Figure 1. The onset of paralysis in the neuroprotective study (9 $\pm 1.4 ; 11 \pm 1.6 ; 14 \pm 1.7 ; 12 \pm 1.6 ; 25 \pm 2.222 \pm 2.0 \mathrm{~min}$.)

$* \mathrm{p}<0.05$ vs (negative) control; $\$ \mathrm{p}<0.05$ vs piracetam

\section{Duration of paralysis}

During an observation time of 2 hours, $12 \mathrm{mg}$ of extract showed a maximum protective effect on the duration of paralysis $(59 \pm 2.0 \mathrm{~min})$ induced by pancuronium bromide followed by $9 \mathrm{mg}$ with a duration time of $77 \pm 2.5$ minutes. This is significantly $(\mathrm{p}<0.05)$ shorter than negative controls $(112 \pm 5.0 \mathrm{~min}$ ) but only $12 \mathrm{mg}$ of extract shortens duration of paralysis also significantly towards positive control of piracetam $(81 \pm 2.8 \mathrm{~min}$, $\mathrm{p}<0.05$ ). The other treatment groups with $6 \mathrm{mg}$ and $15 \mathrm{mg}$ of the extract showed $83 \pm 3.4$ and $83 \pm 3.2$ min. duration time of paralysis comparable to piracetam. In other words, duration of paralysis was shorter over the whole range of dosage from $6 \mathrm{mg}$ to $15 \mathrm{mg}$ of extract as compared to negative control, with $12 \mathrm{mg}$ being also significantly more effective than piracetam 30mg (Fig.2).

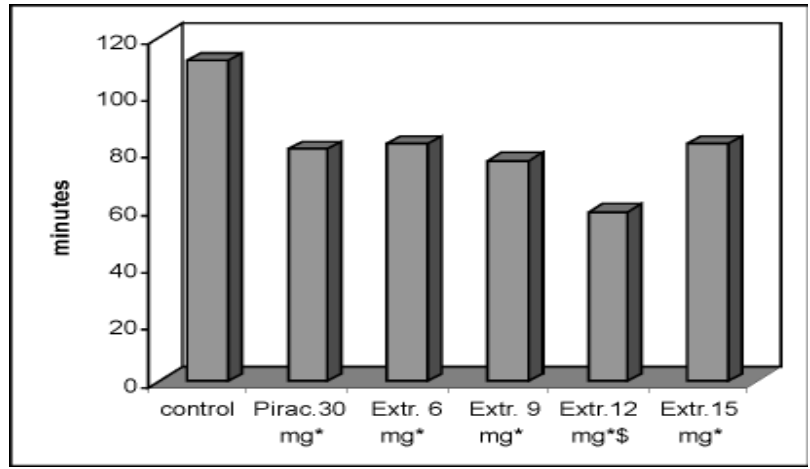

Figure 2. Duration of paralysis during 2 hours of observation (112 $\pm 5.0 ; 81 \pm 2.8 ; 83 \pm 3.4 ; 77 \pm 2.5 ; 59 \pm 2.0 ; 83 \pm 3.2 \mathrm{~min}$.)

$* \mathrm{p}<0.05$ vs (negative) control; $\$ \mathrm{p}<0.05$ vs piracetam 


\section{Complete recovery}

Complete recovery took about 2 hours in the control group which had only been given water through the nasogastric tube, i.e., these frogs did not wake up before 2 hours of observation. Based on this data, the groups were catagorised as follows: unawake after 2 hours $(>120$ minutes $)=$ score 5 ; awake between $90-120$ $\min =$ score $4 ; 60-90 \mathrm{~min}=$ score $3 ; 30-60 \mathrm{~min}=$ score 2 ; and less than 30 minutes $=$ score 1 .

The negative control group thus scored 4.25 and the piracetam group as positive control scored 3.8. Administration of 12 and $15 \mathrm{mg}$ of extract resulted in recovery scores of 2.4 and 2.5, respectively (Fig. 3), which values are significantly different from both negative control and piracetam groups $(p<0.05)$. The other two treatment groups with $6 \mathrm{mg}$ and $9 \mathrm{mg}$ of extract and a score of 3.0 were also more effective than piracetam, although the difference is not significant. However, all treatment groups differ significantly from the negative control group. Also in this experiment, the administration of $12 \mathrm{mg}$ of extract shows a maximum effect (Fig. 3). Statistical evaluation was performed with the original values in minutes before scoring.

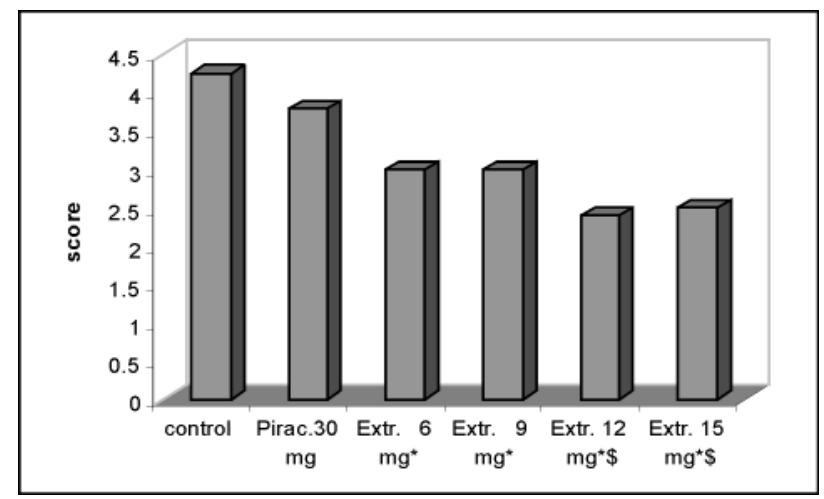

Figure 3. Recovery score within 2 hours of observation (protective effect)

$* \mathrm{p}<0.05$ vs (negative) control; $\$ \mathrm{p}<0.05$ vs piracetam

\section{Group II: Neurotherapeutic effect (Figs.4 and 5).}

\section{Duration of paralysis}

This experiment resembles that one shown in Fig. 2, the difference is that the extract was now administered 10 min after the injection of pancuronium bromide. The results are depicted in Figure 4.
The therapeutic effect of Acalypha indica Linn. extract is characterized by a maximum at the group which obtained $9 \mathrm{mg}$ per frog. The difference in duration time of paralysis $(20 \pm 1.2 \mathrm{~min} v s \quad 115 \pm 5.4 \mathrm{~min}$ in negative controls) is highly significant $(\mathrm{p}=0.000)$ and also vs the positive control group which had received $30 \mathrm{mg}$ of piracetam ( $40 \pm 2.0 \mathrm{~min} ; \mathrm{p}=0.012)$.

All other values in the dose range of $6-15 \mathrm{mg}$ of extract per frog also demonstrated significantly shorter duration times of paralysis between $44 \pm 2.2$ and $65 \pm 3.0$ minutes ( $\mathrm{p}=0.000-0.003)$ vs negative controls $(115 \pm 5.4$ min), comparable to the positive control group which had obtained piracetam ( $40 \pm 2.2 \mathrm{~min}$; $\mathrm{p}=0.145-0.455)$. Hence, except for the group with $9 \mathrm{mg}$ of extract, no significant difference to the piracetam group was observed (Fig. 4).

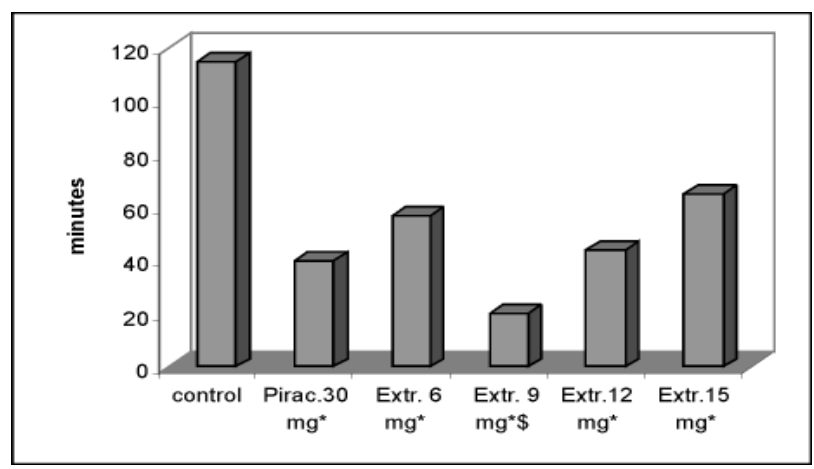

Figure 4. Therapeutic effect on duration of paralysis during 2 hours of observation. (115 $\pm 5.4 ; 40 \pm 2.0 ; 57 \pm 2.6$;

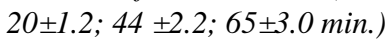

$* \mathrm{p}<0.000$ vs (negative) control; $\$ \mathrm{p}<0.012$ vs piracetam

\section{Complete recovery}

After 2 hours of observation, all values in the dose range of $6-15 \mathrm{mg}$ of extract per frog demonstrated significantly shorter complete recovery times from paralysis between $27 \pm 1.4 \mathrm{~min}$ for the group with $12 \mathrm{mg}$ and $44 \pm 1.6 \mathrm{~min}$ for the doses of $9 \mathrm{mg}$ and $15 \mathrm{mg}$ $(\mathrm{p}=0.000-0.003)$ vs negative controls $(115 \pm 5.6 \mathrm{~min})$ and positive controls piracetam $(58 \pm 2.0 \mathrm{~min} ; \mathrm{p}=0.000$ 0.316 ). These results were scored in the same way as explained in the context of Fig. 3 and are depicted in Fig.5: negative control $=$ score 4.25 ; piracetam $=3.1$; extract $6 \mathrm{mg}=2.3$; extracts $9 \mathrm{mg}$ and $15 \mathrm{mg}=1.7$; extract $12 \mathrm{mg}=1.4$. 


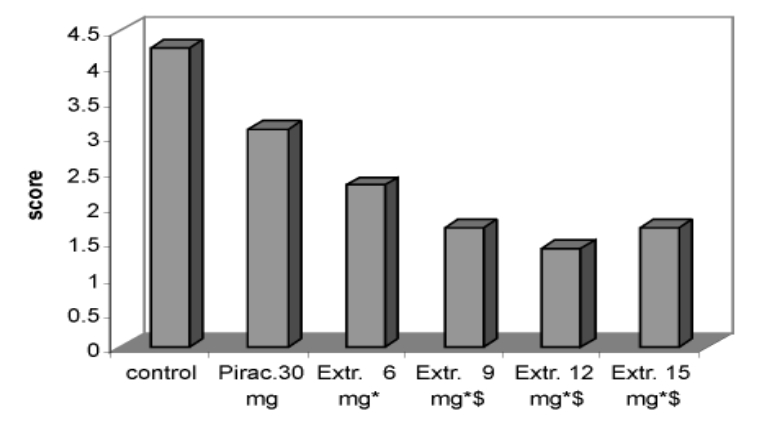

Figure 5. Recovery score within 2 hours of observation (therapeutic effect)

${ }^{*} \mathrm{p}<0.000-0.004$ vs (negative) control; $\$ \mathrm{p}<0.000$ vs piracetam

\section{Summary}

A significant neuroprotective effect of Acalypha indica Linn. extract on frogs paralyzed with pancuronium bromide in vivo has been shown at a dosage of $12 \mathrm{mg}$ per frog or $400 \mathrm{mg} / \mathrm{kgBW}$, while the whole dose range of extract $(6-15 \mathrm{mg}$ or $200-500 \mathrm{mg} / \mathrm{kgBW}$ ) exerted a significant therapeutic effect compared to the negative control group with a maximum effect at $9-12 \mathrm{mg}$ or $300-400 \mathrm{mg} / \mathrm{kgBW}$.

\section{DISCUSSION}

\section{Acalypha indica Linn. (akar kucing) $)^{10,11}$}

Nahrstedt et al. isolated acalyphin from Acalypha indica Linn. and published its structure in $1982{ }^{10}$ and it was considered the active compound ${ }^{11}$ although a variety of other compounds have been isolated from Acalypha indica ${ }^{12,13}$. Various extracts from this plant had been shown to have diurectic ${ }^{14}$, antimicrobial ${ }^{15}$, scavenging activity ${ }^{16}$, and antifertility ${ }^{17}$ effects, however not all extracts were decocts from the plant's roots as proven for the antiurisemic activity in rats ${ }^{18}$.

In our study, a standardised aqueous extract from the roots was applied.

\section{Frogs as animal models}

Frogs have been used classically for demonstration of neuro-musculoskeletal effects in the laboratories of physiology and pharmacology and numerous studies generally using this ex vivo neuro-musculoskeletal model support its validity ${ }^{7-8}$. Therefore, also our working group used this ex vivo model in a preliminary study. ${ }^{6}$ The present study demonstrating protective and therapeutic effects of Acalypha indica Linn. (akar kucing) extract in living frogs provides evidence that frogs can be used as an in vivo animal model for innervation, both in peripheral and central nervous systems.

\section{Piracetam}

From innumerous publications on the effects of piracetam, only few which may be considered in the context of "positive control" in the present study are selected. Clinically doses of piracetam up to grams are applied in therapy and the official safety data sheet denotes $\mathrm{LD}_{50 \text { (mouse) }}$ of $2,000 \mathrm{~g} / \mathrm{kgBW}$. There for, in our study the dosage of $1,000 \mathrm{mg} / \mathrm{kgBW}$ was chosen, equivalent to $30 \mathrm{mg}$ per frog. Piracetam is thought have impact on acetylcholine via muscarinic cholinergic receptors and on NMDA glutamate receptors and may modulate ion channels and thus membrane permeability 19-22. Furthermore, in animal models there appears to be an effect on cerebral/neural mitochondrial energy metabolism, electron transport and ATP synthesis ${ }^{23-24}$.

\section{Dosage finding of the extract}

The effective dose in frogs in vivo, 20 times the dose of ex vivo study (200-500 mg/kg BW or 6-15 mg/frog, at an average body weight of $30 \mathrm{~g}$ ), was lower than ex vivo study using neuromuscular junction's model .i.e. $10 ; 15 ; 20 ; 25 \mathrm{mg} / \mathrm{sample}$, because of their body weight, both the protective and therapeutic effect ${ }^{6}$.

\section{Effects}

In the neuroprotective set of experiments, the extract is superior over piracetam $30 \mathrm{mg}$ which is even statistically significant at higher extract dosages of $12-15 \mathrm{mg}$. From these experiments different from the plant extract, piracetam does not exert protective efficacy.

In the therapeutic set of experiments, piracetam exerts a siginificant effect vs controls, as does the plant extract at all dosages from 6-15mg. However, at a dose of $9 \mathrm{mg}$, the extract is significantly more effective than $30 \mathrm{mg}$ of piracetam.

In both sets of experiments, the plant extract exerts a bellshaped pharmacodynamic action with peaks at $12 \mathrm{mg}$ for the protective effect and at $9 \mathrm{mg}$ for therapy. These dosages are also significantly superior over our reference compound piracetam at the applied dose of $30 \mathrm{mg}$. 
These results are interpreted that the extract acts as a competitive inhibitor to pancuronium bromide in neuromuscular junction both in neuroprotective and neurotheraptic sets of experiments, while piracetam did not show comparable neuroprotective effect. Hence, in our model, piracetam can be used as neurotherapic compound at neuromuscular junction, but its mechanism of action appears to be different from the Acalypha indica extract. It is not clear whether one of the "active" compounds of Acalypha indica like acalyphin, is responsible for the effects seen in our sets of experiments or rather their metabolites ${ }^{25}$. Furthermore, as often in herbal medicines, it is the specific composition of extracts that causes pharmacological effects.

The effective dose of this extract as neurotherapeutic agent was lower $(300 \mathrm{mg} / \mathrm{kgBW})$ than its neuroprotective dosage (400-500 $\mathrm{mg} / \mathrm{kgBW})$. Since the effect was better than that of piracetam the extract of Acalypha indica Linn. will be promising to be choosen as complementary or alternative herbal medicine to treat neurologic disorders, especially in central nervous system although the mechanism of action cannot yet fully be explained.

Although frogs can be used at least as a first or preliminary animal model as demonstrated in this study, further studies have to be conducted with another animal model using mice or rats. Furthermore, the mechanism of action of the extract as a neuroprotecting and neurotherapeutic agent has to be demonstrated yet in central and peripheral nervous systems. To this end a model not using pancuronium bromide should be used in order to exclude that the extract might just counteract this compound in terms of a competitive antagonist. The aim of future studies should also be done to improve the extract as a standardized herbal medicine for the treatment of central or peripheral neural paralysis, either in the central nervous system or in neuromuscular junction.

In conclusion, the results of this study indicate that the extract of Acalypha indica Linn. has neuro-protective and neurotherapeutic effects in frogs in vivo. From our interpretation it is suggested that the extract acts as a competitive inhibitor to pancuronium bromide in neuromuscular junction, both in neuroprotective and neurotherapeutic sets of experiments. However, further studies should be performed in other animal models to prove its mechanism of action in preclinical pharmacokinetic and pharmacodynamic studies.

\section{Acknowledgments}

The greatest appreciation goes to the head of DRPM UI who provided funds for the study project through Supreme Research University of Indonesia (Riset Unggulan Universitas Indonesia). We also confer our gratitude to all supervisors and medical students of class 2006-2007 who have participated in this study. Furthermore, the authors are gratefully obliged to Prof. Dr. Hans-Joachim Freisleben for his assistance in writing the manuscript.

\section{REFERENCES}

1. Misbach Y, Kalim H. Stroke mengancam usia produktif. http://www.medicastore.com/stroke/\#atas. 2007 [August 26, 2009]

2. Reynolds JEF (ed.). Piracetam In:Martindale's The Extra Pharmacopeia. $31^{\text {st }}$ ed. London 1995:1742.

3. Anonymous. Celery. http://Id.wikipedia.org/wiki/seledri. July.23.2009 [August 26,2009]

4. Ziment I, Rotblatt M. Garlic (Allium sativum). Evidence based of herbal medicine. Harley\&Belfus, Inc., Philadelphia: 2002:193-200.

5. Dalimarta S. Atlas tumbuhan obat indonesia. Puspa Swara Jilid 3. Jakarta: 2005: 62.

6. Purwaningsih EH, Ibrahim N, Zain H, Tedjo A. Neuroprotection and neuro-therapy effects of Acalypha indica Linn. Water Extract ex vivo on Musculus gastrocnemius Frog. J Makara. 2008;2 (12):71-6

7. Mệme W, Léoty C. Cyclopiazonic acid and thapsigargin reduce $\mathrm{Ca}^{2+}$ influx in frog skeletal muscle fibres as a result of $\mathrm{Ca}^{2+}$ store depletion. Act Physiol Scand. 2001; 173(4): 391-9.

8. Shirokova N, Rios E. Caffeine enhances intramembranous charge movement in frog skeletal by increasing cytoplasmic $\mathrm{Ca}^{2+}$ concentration. J Physiol.1996; 493: 341-56.

9. Norman GR, Streiner DL (eds). Biostatistics: The Bare essentials. Mosby-Year Book Inc. London 1994: pp. 56-8, 182-201

10. Nahrstedt A, Kant JD, Wray V. Acalyphin, a cyanogenic glucoside from Acalypha indica. Phytochemistry. 1982; 21(1):101-5.

11. Talapatra B, Goswami S, Talapatra SK. Acalyphamide, a new amide and other chemical constituents of Acalypha indica Linn. Ind J Chem. 1981;20B:974-7.

12. Hungeling M, Lechtenberg M, Fronczek FR, Nahrstedt A. Cyanogenic and non-cyanogenic pyridone glucosides from Acalypha indica (Euphorbiaceae). Phytochemistry. 2009:70(2):270-7.

13. Siregar AH. Acalypha L. Plant resources of South-East Asia No. 12(2). In: (van Valkenburg JLCH and Bunyapraphatsara $\mathrm{N}$, eds.) Medicinal and poisonous plants 2. Backhuys Publishers. Leiden. 2001: 31-6.

14. Das AK, Ahmed F, Biswas NN, Dev S, Masud MM. Diuretic activity of Acalypha indica. Dhaka Univ. J Pharmaceutical Sciences. 2005;4(1):1-3. 
15. Hiremath SP, Badami S, Swamy HKS, Biradar JS. Antimicrobial activity of various extracts of Acalypha indica (Euphorbiaceae). Ind J Microbiol. 1993;33:75-7

16. Balakrishnan N, Panda AB, Raj NR, Shrivasta A, Orathani $\mathrm{R}$. The evaluation of nitric oxide scavenging activity of Acalypha indica Linn. root. Asian J Research Chem. 2009;2(2):148-50

17. Hiremath SP, Rudresh K, Badami S, Patil SB, Patil SR. Postcoital antifertility activity of various extracts of Acalypha indica L. J Ethnopharmacol. 1999;67(3):253-8

18. Azizahwati, Wiryowidagdo S, Prihandini E. Efek penurunan kadar asam urat darah pada tikus putih jantan dari rebusan akar tanaman akar kucing (Acalypha indica Linn.). Jurnal Bahan Alam Indonesia. 2005;4(1):213-8.

19. Winnicka K, Tomasiak M, Bielawska A. Piracetam old drug with novel properties. Acta Pol Pharm. 2005;62(5):405-9

20. Gouliaev AH, Senning A. Piracetam and other structurally related nootropics. Brain Research Reviews. 1994;19(2):180-222.
21. Müller WE, Eckert GP, Eckert A. Piracetam: novelty in a unique mode of action. Pharmacopsychiatry. 1999;32Suppl(1):2-9.

22. Grau M, Montero B. Effect of piracetam on electrocorticogram and local cerebral glucose utilization in the rat. General Pharmacology. 1987;18(2):205-11.

23. Nickolson VJ, Wolthuis OL. Effect of the acquisitionenhancing drug piracetam on rat cerebral energy metabolism. Comparison with naftidrofuryl and methamphetamine. Biochem Pharmacol. 1976;25(20):2241-4.

24. Tacconi MT, Wurtman RJ. Piracetam: physiological disposition and mechanism of action. Advances in Neurology. 1986;43: 675-85.

25. Mills S, Bone K (eds). Principles of herbal pharmacology. In: Principles and Practice of Phytotherapy. Churchill Livingstone Publ. London 2000: 22-79. 